\title{
Eponyms of medical conditions linked to Eosinophils; a tabulation overview
}

\section{Nora Mohammed Al-Aboud}

\author{
College of Applied Sciences, Umm Al-Qura University, Makkah, Saudi Arabia
}

Corresponding author: Dr. Nora Mohammed Al-Aboud, E-mail: amoa65@hotmail.com

Eosinophils are multifunctional granular leukocytes. They are one of the immune system components responsible for combating multicellular parasites and certain infections. Eosinophils are implicated in the pathogenesis of a wide variety of disorders, including asthma, helminth infection, and rare hypereosinophilic syndromes [1].

In Table 1; We listed selected eponymous medical conditions linked to Eosinophils.

Table 1: Selected eponymous medical conditions linked to Eosinophils

\begin{tabular}{|c|c|}
\hline $\begin{array}{l}\text { Eponymous medical conditions } \\
\text { linked to Eosinophils }\end{array}$ & Remarks \\
\hline Charcot-Leyden crystals $[2,3]$ & $\begin{array}{l}\text { These are colorless microscopic crystals found in the sputum of asthma patients, or in the fecal matter of amoebic } \\
\text { and ulcerative colitis. } \\
\text { Friedrich Albert von Zenker was the first to notice these crystals, doing so in } 1851 \text {, after which they were described } \\
\text { jointly by Jean-Martin Charcot and Charles-Philippe Robin in 1853, then in } 1872 \text { by Ernst Viktor von Leyden. } \\
\text { Friedrich Albert von Zenker (1825-1898), (Fig. 1), was a German pathologist and physician, celebrated for his } \\
\text { discovery of trichinosis and the first description of the craniopharyngioma in } 1857 . \\
\text { Charles-Philippe Robin (1821-1885), (Fig. 2) was a French anatomist. } \\
\text { Jean-Martin Charcot (1825-1893), (Fig. 3), was a French neurologist and pathologist. } \\
\text { Ernst Viktor von Leyden (1832-1910), (Fig. 4), was a German internist }\end{array}$ \\
\hline Churg-Strauss syndrome $[4,5]$ & $\begin{array}{l}\text { Alternatively known as eosinophilic granulomatosis with polyangiitis (EGPA). It is characterized by disseminated } \\
\text { necrotizing vasculitis with extravascular granulomas occurring exclusively among patients with asthma and } \\
\text { tissue eosinophilia. } \\
\text { Churgh-Strauss syndrome was first described by } 2 \text { American pathologists Jacob Churg (1910-2005), (Fig. 5), } \\
\text { and Lotte Strauss (1913-1985), (Fig. 6), at Mount Sinai Hospital in New York City in } 1951\end{array}$ \\
\hline $\begin{array}{l}\text { Löffler's syndrome and Löffler's } \\
\text { endocarditis }[6,7]\end{array}$ & $\begin{array}{l}\text { Löffler's syndrome is another name for Eosinophilic pneumonia. One fourth of Loeffler's syndrome patients are } \\
\text { idiopathic, although the most common etiologic causes include parasites. } \\
\text { Whereas, Loeffler endocarditis is a form of restrictive cardiomyopathy which affects the endocardium and occurs } \\
\text { with proliferation of Eosinophils. } \\
\text { Both conditions are named after Wilhelm Löffler (1887-1972), (Fig. 7), who was a Swiss doctor }\end{array}$ \\
\hline Shulman disease $[8,9]$ & $\begin{array}{l}\text { This is another name for eosinophilic fasciitis (EF) is a rare connective tissue disease characterized by } \\
\text { symmetrical and painful swelling with a progressive induration and thickening of the skin and soft tissues. Named } \\
\text { for Lawrence E. Shulman (1919-2009), (Fig. 8), who was an American Rheumatologist }\end{array}$ \\
\hline Wells syndrome [10] & $\begin{array}{l}\text { This is another name for eosinophilic cellulites. Named after George Crichton Wells (1914-1999), (Fig. 9), who was } \\
\text { a dermatologist at St Thomas's Hospital and St. John's Hospital for Diseases of the Skin (now closed) }\end{array}$ \\
\hline
\end{tabular}

How to cite this article: Al-Aboud NM. Eponyms of medical conditions linked to Eosinophils; a tabulation overview. Our Dermatol Online. 2017;7(3):366-368. Submission: 11.02.2016; Acceptance: 02.04.2016

DOI: 10.7241 /ourd.20173.107 
www.odermatol.com

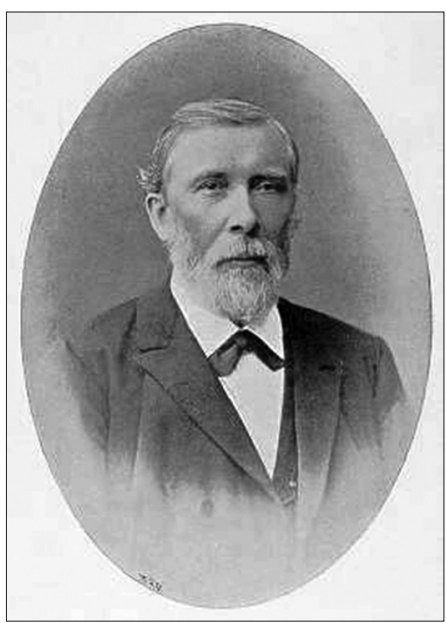

Figure 1: Friedrich Albert von Zenker (1825-1898).

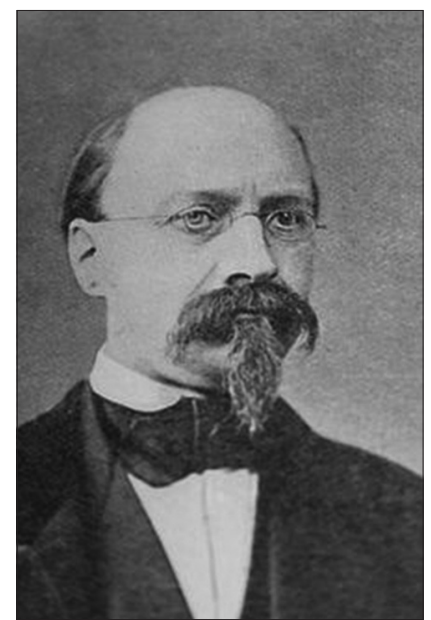

Figure 2: Charles-Philippe Robin (1821-1885).

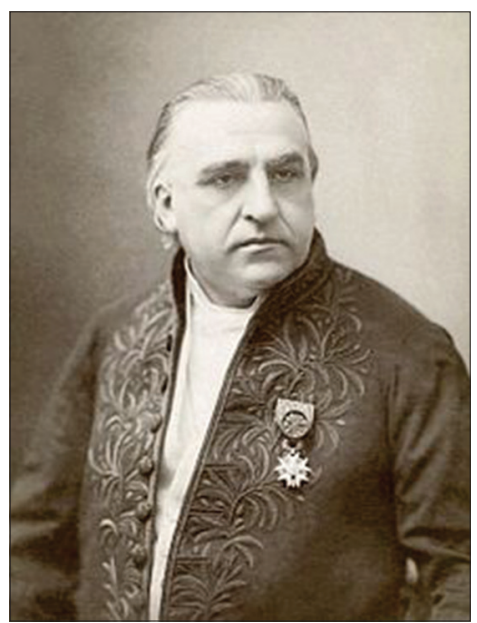

Figure 3: Jean-Martin Charcot (1825-1893).

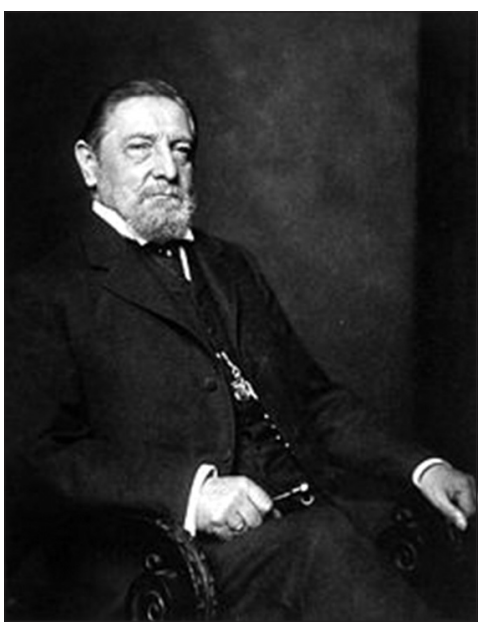

Figure 4: Ernst Viktor von Leyden (1832-1910).

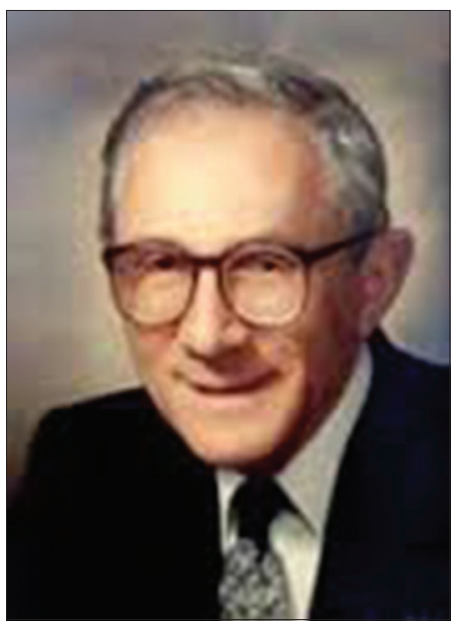

Figure 5: Jacob Churg (1910-2005).

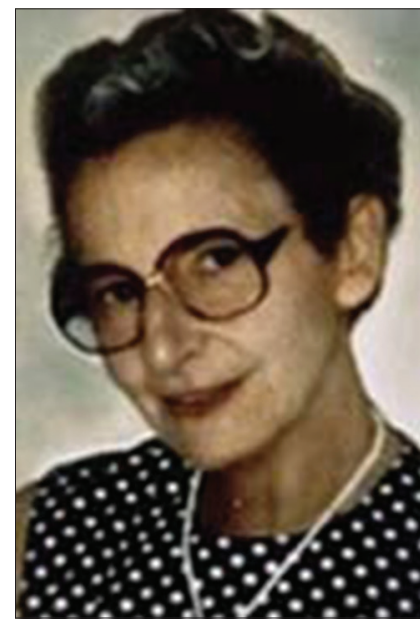

Figure 6: Lotte Stauss (1913-1985). 
www.odermatol.com

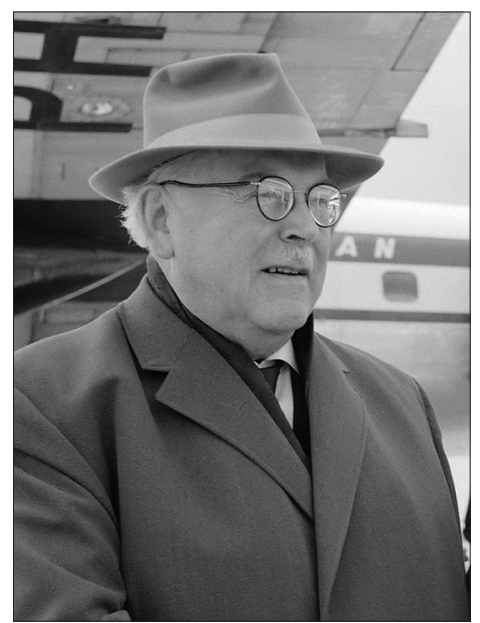

Figure 7: Wilhelm Löffler (1887-1972).

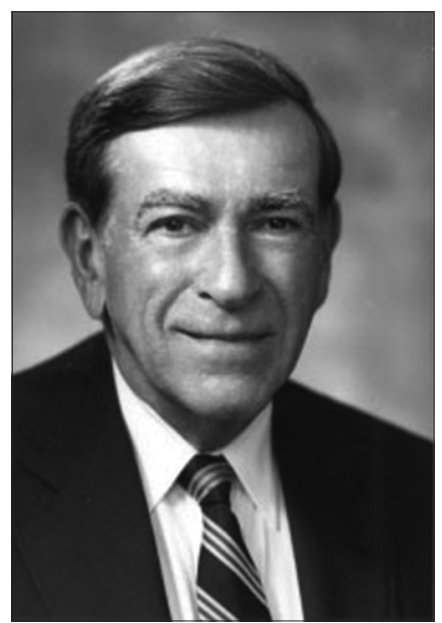

Figure 8: Lawrence E. Shulman (1919-2009).

\section{REFERENCES}

1. Khoury P, Grayson PC, Klion AD. Eosinophils in vasculitis: characteristics and roles in pathogenesis. Nat Rev Rheumatol. 2014;10:474-83.

2. Khrizman P, Altman JK, Mohtashamian A, Peterson L, Chen YH, Tallman MS. Charcot-Leyden crystals associated with acute

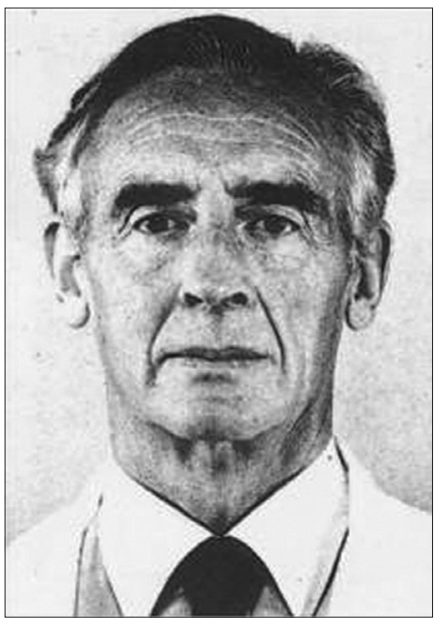

Figure 9: George Crichton Wells (1914-1999).

myeloid leukemia: case report and literature review. Leuk Res. 2010;34:e336-8.

3. Barkhoudarian G, Laws ER. Craniopharyngioma: history. Pituitary. 2013;16:1-8.

4. Grishman E. The man behind the eponym. Dr. Jacob Churg. Am J Dermatopathol. 1986;8:358-9.

5. Persson UN, Hansen BU, Odeberg H. Jacob Churg and Lotte Strauss. They were brought together by a mutual destiny]. Lakartidningen. 1995;92:1797-8.

6. Portmann ML. [Wilhelm Löffler (1887-1972) as a medical historian]. Gesnerus. 1979;36:63-73.

7. Ekin S, Sertogullarindan B, Gunbatar H, Arisoy A, Yildiz H. Loeffler's syndrome: an interesting case report. Clin Respir J. 2016;10:112-4.

8. Lebeaux D, Sène D. Eosinophilic fasciitis (Shulman disease). Best Pract Res Clin Rheumatol. 2012;26:449-58.

9. Hahn BH, Lockshin MD. Lawrence E. Shulman, MD, PhD, 1919-2009. Arthr Rheumat. 2010;62:311.

10. Al Aboud K, Al Aboud A. Eponyms in the dermatology literature linked to United Kingdom. Our Dermatol Online. 2013;4(Suppl. 2):417-9.

Copyright by Mohammed Al-Aboud. This is an open access article distributed under the terms of the Creative Commons Attribution License, which permits unrestricted use, distribution, and reproduction in any medium, provided the original author and source are credited.

Source of Support: Nil, Conflict of Interest: None declared. 